\title{
Kehidupan Masyarakat Multi Agama Desa Bulurejo Purwoharjo Banyuwangi dalam Membangun Kerukunan Hidup Antar Umat Beragama
}

\author{
Harjianto $^{1 *}$, Intan Daurotus $\mathrm{M}^{2}$, Bayu Indra Permana ${ }^{3}$ \\ 1,2,3 Universitas PGRI Banyuwangi \\ Correspondence email: hr.bwin@gmail.com ${ }^{1 *}$, intandaurotus54466@gmail.com ${ }^{2}$, bayuindraper@gmail.com ${ }^{3}$
}

\begin{abstract}
Abstrak. Kerukunan umat beragama merupakan pilar kerukunan nasional yang dinamis harus terus dipelihara dari waktu ke waktu. Desa Bulurejo merupakan desa yang unik karena disini memiliki banyak perbedaan namun mereka bisa hidup rukun dan berdampingan. Di desa Bulurejo masyarakatnya multi Agama yaitu Islam, Hindu, Kristen, Katolik, dan Budha yang hidup berdampingan dan membaur menjadi satu. Perbedaan dan keberagaman yang ada menjadi salahsatu keuunggulan Desa Bulurejo. Tujuan yang ingin dicapai dalam penelitian ini adalah untuk mengetahui kehidupan masyarakat di Desa Bulurejo dalam membangun kerukunan hidup antar umat beragama, serta mengetahui bentuk-bentuk kegiatan apa saja yang menggambarkan kerukunan atar umat beragama di Desa Bulurejo. Jenis penelitian ini adalah kualitatif deskriftif, Dengan pendekatan fenomenologis dengan subjek yaitu pemerintahan desa, tokoh agama, dan tokoh masyarakat. Hasil dari penelitian ini adalah Desa Bulurejo merupakan desa yang multi agama yang memiliki keberagaman agama dan budaya. Desa Bulurejo memiliki kerukunan umat beragama yang bisa dikatakan sangat baik. Hal ini di tunjukan dengan kebersamaan dalam kehidupan sehari-hari serta melakukan berbagai macam bentuk kegiatan yang dilakukan secara bersama-sama diantaranya yaitu 1). Pertemuan lintas agama yang dilakukan setiap tiga bulan sekali; 2) Kegiatan bersih desa diikuti oleh semua warga masyarakat: 3). Kegiatan-kegiatan keagamaan yang dalam pelaksanaanya melibatkan umat lainya seperti kegiatan keagamaan umat Islam, umat Hindu, umat Kristen, umat Katolik, dan umat Budha; 4). Kegiatan memperingati HUT RI.
\end{abstract}

Kata Kunci: multi agama; kerukunan hidup

Abstract. Religious harmony is a dynamic pillar of national harmony that must be maintained from time to time. Bulurejo village is a unique village because here there are many differences but they can live in harmony and side by side. In the village of Bulurejo the people are multi-religious, namely Islam, Hinduism, Christianity, Catholicism and Budha who live side by side and blend into one. The diversity that exists is one of the main advantages of the Village of Bulurejo. The aim of this research is to find out the life of the people in the village of Bulurejo in building harmony between religions, as well as knowing the forms of activities that describe the harmony of the religious community in the village of Bulurejo. This type of research is descriptive qualitative, with a phenomenological approach to the subject of village governance, religious leaders, and community leaders. The results of this study are the Bulurejo Village is a multi-religious village that has a diversity of religions and cultures. Bulurejo village has a religious harmony which can be said to be very good. This is indicated by togetherness in everyday life and doing various forms of activities carried out together including 1). Interfaith meetings conducted every three months; 2) Village cleaning activities are followed by all community members: 3). Religious activities in the implementation involve other people such as religious activities of Muslims, Hindus, Christians, Catholics, and Buddhist: 4). Activities commemorating the Republic of Indonesia Anniversary.

Keywords: multi relegion; living harmony

\section{PENDAHULUAN}

Indonesia merupakan Negara pluralisme yang memiliki perbedaan yang mendasar salah satunya yang berkaitan dengan kehidupan beragama. Kehidupan beragama dijamin oleh Undang-Undang Dasar 1945 pasal 28E ayat (1): "setiap orang bebas memeluk agama dan beribadah menurut agama, memilih pekerjaan, memilih kewarganegaraan, memilih tempat tinggal di wilayah Negara dan meninggalkannya, serta berhak kembali”. Pasal 28E (2) Undang-Undang Dasar 1945 juga menyatakan bahwa setiap orang berhak atas kebebasan meyakini kepercayaan. Selain itu dalam Pasal 28I ayat (1) Undang-Undang Dasar 1945 juga diakui bahwa hak untuk beragama merupakan hak asasi manusia. Selanjutnya Pasal 29 ayat (2) Undang-Undang
Dasar 1945 juga menyatakan bahwa Negara menjamin kemerdekaan tiap-tiap penduduknya untuk memeluk agama

Negara Kesatuan Republik Indonesia sebagai Negara kepulauan terbesar di dunia dengan berbagai segi kemajemukan sosial budaya, akan tetapi perbedaan ini menjadi gejala yang harus selalu diperhitungkan dalam mewujudkan keutuhan dan persatuan nasional Indonesia. Sebagai Negara kepulauan yang memiliki banyak suku, bahasa, dan agama Indonesia dipersatukan oleh pancasila sebagai pedoman bagi rakyat Indonesia dengan semboyan "Bhineka Tunggal Ika" yang artinya meskipun berbeda-beda tetapi tetap satu dalam kesatuan Negara Kesatuan Republik Indonesia. Untuk itulah 
sebagai rakyat Indonesia sangat mengayomi dasar Negara Indonesia.

Suatu kenyataan sosiologis bahwa bangsa Indonesia terdiri dari masyarakat multikultural yang harus dijunjung tinggi, dihormati, dan terus dipertahankan. Karena adanya pengakuan atas keberagaman inilah bangsa Indonesia terbentuk. Salah satu bentuk keberagaman yang terdapat di Indonesia adalah persoalan agama. Indonesia bukan negara sekuler atau hal-hal yang bernuansa agama tidak boleh masuk ke dalam pemerintahan, bukan pula negara agama, akan tetapi pengakuan terhadap agama oleh negara hanya meliputi enam agama saja, yaitu Islam, Hindhu, Budha, Kristen, Katolik, dan Kong Hu Chu.

Kehidupan masyarakat yang selalu terjalin dengan baik adalah suatu hal yang sangat mewujudkan bahwa masyarakat memiliki sikap rasa saling menghormati, saling menyayangi, saling membantu dan saling menghargai dalam bentuk perbedaan-perbedaan. Suatu wilayah kecil di kawasan Banyuwangi selatan yaitu desa Bulurejo, Kecamatan Purwoharjo yang memiliki suatu kehidupan masyarakat yang berbeda dari segi pikiran, pendapat, ilmu, kebiasaan-kebiasaan dan kepercayaan yang menggambarkan bahwa wilayah tersebut merupakan gambaran dari kelima sila dalam Pancasila yang memberikan jaminan untuk selalu hidup rukun aman dan tentram di bumi Indonesia ini. Didukung dengan peraturan-peraturan daerah, hukum Negara, hukum agama dan perundang-undangan yang memikat sebagai warga Negara agar tetap hidup rukun dan berdampingan.

Kerukunan umat beragama adalah hal yang sangat penting untuk mencapai sebuah kesejahteraan hidup di negeri ini dan keberadaanya tidak bisa ditawar lagi. Manusia harus menjunjung tinggi nilai-nilai keberagaman penganut agama dan kepercayaanb yang ada di Indonesia, karena dengan hidup rukun maka sudah menjaga nama baik Bangsa dan Negara.

Sebagai masyarakat multi agama, maka sudah sewajarnya harus menjaga sikap terhadap pemeluk agama lain, begitupun sebaliknya pemeluk agama yang lain juga harus menjaga sikap. Maka akan tercipta kerukunan antar umat beragama, dengan saling menjaga dan saling membantu dalam kehidupan sehari-hari. Desa bulurejo Memiliki agama lebih dari satu yaitu Agama Islam, Kristen, dan hindu.

Satu wilayah yang memiliki tiga agama bukan hal yang mudah dalam mencapai kesejahteraan masyarakat, bukan hal yang mudah pula untuk menyatukan dalam perbedaan, dan bukan hal yang mudah juga untuk menjalin suatu keakraban dalam membangun kerukunan umat beragama. Penganut agama pun tersebar di antara pulau, misalnya penganut agama Islam mayoritas di pulau Jawa, Sumatera, Madura, Kalimantan, Sulawesi, Lombok, Sumbawa, Maluku Utara, agama Kristen mayoritas di pulau Irian (Irian Jaya) dan Katolik di pulau Flores, dan Hindu di pulau Bali (Ardiansyah, 2013).

Dasar hukum yang menjamin kebebasan beragama di Indonesia ada pada konstitusi kita, yaitu Pasal 28E ayat (1) Undang-Undang Dasar 1945: "setiap orang bebas memeluk agama dan beribadah menurut agama, memilih pekerjaan, memilih kewarganegaraan, memilih tempat tinggal di wilayah Negara dan meninggalkannya, serta berhak kembali”. Pasal 28E (2) Undang-Undang Dasar 1945 juga menyatakan bahwa setiap orang berhak atas kebebasan meyakini kepercayaan. Selain itu dalam Pasal 28I ayat (1) Undang-Undang Dasar 1945 juga diakui bahwa hak untuk beragama merupakan hak asasi manusia. Selanjutnya Pasal 29 ayat (2) Undang-Undang Dasar 1945 juga menyatakan bahwa Negara menjamin kemerdekaan tiap-tiap penduduknya untuk memeluk agama (Undang-Undang Dasar, 1945, hlm. 13).

Keanekaragaman suku, bahasa, adat istiadat dan agama merupakan suatu yang sering disebut pluralisme, dan pluralisme tidak dapat dipahami dengan mengatakan bahwa masyarakat majemuk, beranekaragam terdiri dari berbagai suku dan agama yang justru menggambarkan masyarakat kecil yang menjadi satu. Di samping itu kemajemukan atau keanekaragaman juga dapat mengandung kerawanan yang dapat memunculkan konflik kepentingan antar kelompok yang berbeda-beda tersebut. Berbagai upaya telah dilakukan oleh pemerintah untuk menggalang persatuan dan kesatuan bangsa. Di antara upaya tersebut adalah pembinaan kerukunan antar umat beragama melalui program peningkatan kerukunan hidup umat beragama. Sikap toleransi antar umat beragama akan menciptakan kerukunan apabila mereka benar-benar paham tentang agamanya, karena semua agama adalah sebuah aturan yang mengajarkan tentang kebaikan, setiap manusia beragama memilki rasa saling ingin mengetahui, satu sama lain, baik dari adat istiadat, bahasa, dan agamanya (Ardiansyah, 2013).

Sebagai gambaran bahwa Kerukunan umat Bergama itu terjalin dengan baik Sejak zaman kemerdekaan, muslim dan nasrani di Kelurahan Kratonan, Kecamatan Serengan Solo, mempunyai tempat ibadah yang saling berdampingan, selalu saling bantu dan saling menghormati satu sama lainnya, tanpa pernah di warnai gesekan sedikitpun Umat Islam di wilayah ini, melaksanakan kegiatan sholat dan ibadah lainnya di masjid Al-hikmah. Sedangkan umat nasrani melaksanakan ibadahnya di Greja Kristen Jawa (GKJ) Joyodiningrat. Uniknya kedua ibadah tersebut saling bersebelahan dan hanya di pisahkan tembok batu bata. Bahkan kedua tempat ibadah tersebut mempunyai alamat yang sama yaitu Jalan Gatot Subroto No.222, Solo. Di gereja tersebut juga di gunakan sebagai sekolah taman kanak-kanak. Sedangkan di masjid masyarakat juga sering memanfaatkan untuk pengajian, TPA (Taman 
Pendidikan Al-Quran), serta kegiatan lainnya. Toleransi juga terlihat dalam kehidupan bermasyarakat sehingga peribadatan kedua umat beragama hingga saat ini berjalan lancar.

Kerukunan umat beragama merupakan pilar kerukunan nasional yang dinamis harus terus dipelihara dari waktu ke waktu. Kerukunan umat beragama dapat di artikan sebuah keadaan hubungan sesama umat beragama yang di landasi toleransi, saling pengertian, saling menghormati, menghargai kesetaraan dalam pengamalan ajaran agama dan kerja sama dalam kehidupan bermasyarakat, berbangsa dan bernegara. Hal tersebut dilandasi atas kesadaran bahwa dalam kehidupan bermasyarakat, terjadi apa yang disebut dengan interindependensi atau perilaku dari dua individu yang berinteraksi satu sama lain, saling membutuhkan dan saling ada ketergantungan. Jika interindependensi menjadi sebuah perinsip dalam kehidupan bermasyarakat, maka kerukunan hidup beragama adalah bagaimana antar umat beragama dapat saling melindungi, memelihara dan mengamankan, bahkan dalam kondisi-kondisi tertentu mungkin dapat meningkatkan sesuatu yang bersifat psikologis dan sosiologis yang dimiliki oleh setiap umat beragama. Dalam tingkat optimis, kerukunan tersebut dapat menyentuh persoalan-pesoalan mendasar yang dihadapi oleh setap umat beragama, seperti membangun struktur dan tata nilai kehidupan yang lebih beradab dan humanis (H. Anasri Nurdin, 2018).

Toleransi antar umat bergama yaitu menyakini bahwa agamaku adalah agamaku dan agamamu adalah agamamu, tetapi disini harus saling respect/menghargai agama orang lain dan tidak boleh memaksakan orang lain untuk menganut agama lain. Serta tidak diperbolehkan untuk menjatuhkan, mengejek-ngejek dan mencela agama orang lain dengan alasan apapun karena sejatinya kita adalah sama-sama menusia yang hidup berdampingan. Sepanjang sejarah agama dapat memberi sumbangsih positif bagi masyarakat dengan memupuk persaudaraan dan semangat kerjasama antar anggota masyarakat. Namun sisi lain, agama juga dapat sebagai pemicu konflik antar masyarakat beragama. Ini adalah sisi negatif dari agama dalam mempengaruhi masyarakat di Indonesia.

Dengan keberagaman suku, bahasa, adat istiadat, dan agama yang merupakan suatu kenyataan yang harus disyukuri sebagai kekayaan bangsa, dengan segala perbedaan-perbedaan yang sangat nyata baik internal maupun eksternal. Berangkat dari suatu hal yang menarik untuk diketahui dalam suatu penelitian, tepatnya di Desa Bulurejo, Kecamatan Purwoharjo, Kabupaten Banyuwangi. Dalam desa tersebut terdapat lima dusun yang memiliki penyebaran agama yang sama rata yaitu dusun bulurejo, dusun ngadirejo, dusun ngadimulyo, dan dusun tambakrejo dengan tiga pemeluk agama yaitu Islam, Kristen Protestan, dan Hindu.
Dari masyarakat multi agama dalam membangun kerukunan umat Bergama, di desa tersebut memiliki segala kekurangan dalam bentuk kerukunan umat Bergama dari segi kemajemukan masyarakat serta kepekaan masyarakat terhadap sesama manusia dan segala kelebihan dalam bentuk interaksi sosial yang dilakukan, rasa solidaritas antar masyarakat dan sikap tidak sadar terhadap lingkungan. Kelebihan yang terlihat sebagai gambaran awal Dari sumber yang didapatkan oleh peneliti bahwa lokasi atau tempat ini menarik untuk dilakukan penelitian dibandingkan dengan wilayahwilayah yang lain yaitu, desa Bulurejo merupakan desa yang memiliki umat Bergama tidak bergerombol/satu grup, namun mereka menyebar di suatu dusun diantara empat dusun tersebut. Dengan tempat ibadah yang tersebar di dusun-dusun.

Tujuan dari penelitian ini adalah 1). untuk mengetahui Bagaimanakah kehidupan masyarakat Desa Bulurejo Kecamatan Purwoharjo dalam membangun kerukunan hidup antar umat beragama; 2). Apa saja bentuk-bentuk kegiatan yang menggambarkan kerukunan atar umat beragama di Desa Bulurejo Kecamatan Purwoharjo.

\section{METODE}

\section{Desain penelitian}

Jenis penelitian ini adalah kualitatif deskriftif, dengan pendekatan fenomenologis dengan subjek yaitu pemerintahan desa Bulurejo, tokoh agama, dan tokoh masyarakat. Fenomenologi merupakan sebuah pendekatan filsafat yang berpusat pada analisis terhadap gejala yang membanjiri kesadaran manusia (Hasbiansyah, 2005,hlm. 166). Tujuan dengan pendekatan ini untuk menggambarkan fenomena kerukunan umat beragama yang terjadi di dusun-dusun Desa Bulurejo secara sistematis dari suatu fakta secara faktual dan cermat

Adapun teknik Pengumpulan Data yang digunakan peneliti yaitu wawancara, observasi, dan dokumentasi. Dokumentasi yaitu diperoleh dari interaksi bersama warga yang terlibat langsung dalam penelitian. Observasi yang dilakukan peneliti yaitu observasi partisipan dimana peneliti terlibat dan datang langsung ditengah-tengah kegiatan subjek penelitian. Wawancara dilakukan secara langsung dimana peneliti berhadapan langsung dengan narasumber dan menggunakan teknik wawancara tak terstruktur

Analisis data yang digunakan dalam penelitian ini menggunakan model Miles and Huberman yang mengemukakan bahwa aktivitas dalam analisis data kualitatif dilakukan secara interaktif dan berlangsung secara terus menerus sampai tuntas, sehingga datanya sudah jenuh. Aktivitas dalam analisis data, yaitu data reduction, data display, dan conclusion drawing/verification. 
Pengecekan keabsahan data merupakan uji kepercayaan terhadap data dan bertujuan untuk menguji kebenaran data atau informasi yang diperoleh. Dalam penelitian kualitatif dapat dilakukan dengan cara triangulasi. Triangulasi dalam pengujian kredibilitas ini diartikan sebagai pengecekan data dari berbagai sumber dengan berbagai cara, dan berbagai waktu. (Sugiyono, 2017: 189).

Teknik triangulasi dalam penelitian ini dilakukan dengan cara membandingkan data antara hasil wawancara dengan observasi,hasil observasi dengan dokumentasi, serta hasil dokumentasi dengan hasil wawancara.

\section{HASIL DAN PEMBAHASAN}

Desa Bulurejo adalah salah satu desa di Kecamatan Purwoharjo yang mempunyai luas wilayah 1.190,675 ha. Dilihat dari topografi ketinggian wilayah Desa $\pm 100 \mathrm{dpl}$. berada pada 10-400 ketinggian dari permukaan air laut dengan keadaan curah hujan rata-rata $1000 \mathrm{~mm} /$ tahun serta suhu rata-rata antara 27-30 C dengan kelembaban udara rata-rata $70 \%$ per tahun.

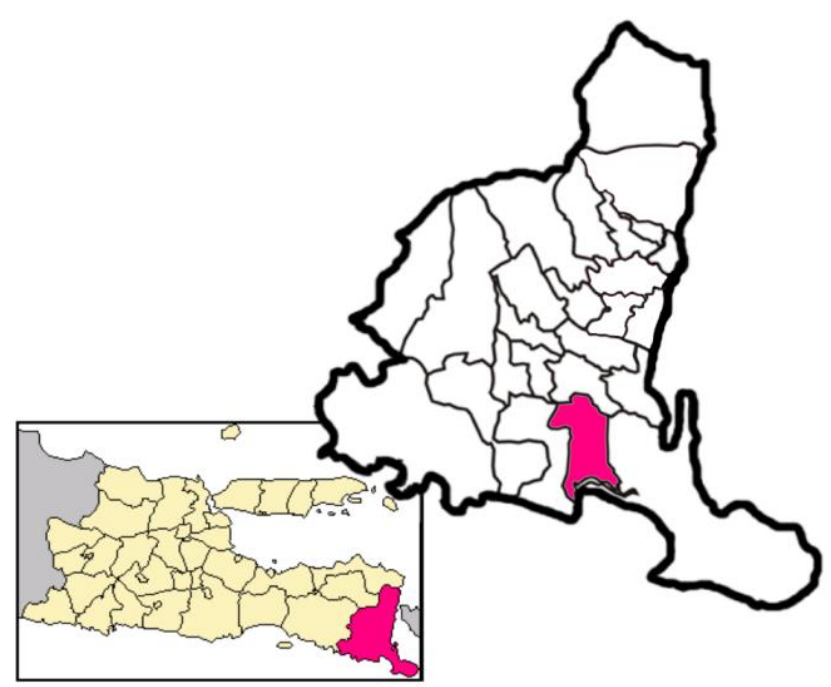

Gambar 1. Peta Wilayah Desa Bulurejo

Sumber : Arsip Desa Bulurejo (2015-2019)

Desa Bulurejo memiliki tempat ibadah yang menyebar di seluruh Dusun yaitu umat Islam, Hindu, Kristen dan Katholik. yang memiliki jumlah Masjid 12 buah, Langgar/Surau/Mushola 41 buah, Gereja Kristen Protestan 2 buah, Gereja Katholik 2 buah, dan Pura 4 buah.

Tabel 1. Tempat Ibadah

\begin{tabular}{ll}
\hline \multicolumn{1}{c}{ Keterangan } & \multicolumn{1}{c}{ Jumlah } \\
\hline Masjid & 12 buah \\
Langgar/Surau/Mushola & 41 buah \\
Gereja Kristen Protestan & 2 buah \\
Gereja Katholik & 2 buah \\
Pura & 4 buah
\end{tabular}

Sumber : Arsip Desa Bulurejo (2015-2019)
Lima agama yang yang dianut oleh warga masyarakat Desa Bulurejo yaitu Islam, Hindu, Kristen, Katholik, dan Budha. Dengan jumlah Umat Islam lakilaki 2538 orang dan perempuan 2374 orang, Umat Kristen laki-laki 411 orang dan perempuan 519 orang, Umat Katholik laki-laki 403orang dan perempuan 386 orang, Umat Hindu laki-laki 862 orang dan perempuan 811orang, dan Umat Budha perempuan 1 Orang

Tabel 2. Jumlah Pemeluk Agama/Aliran Kepercayaan

\begin{tabular}{l|c|c}
\hline \multicolumn{1}{c|}{ Agama } & Laki-laki & Perempuan \\
\hline Islam & 2538 orang & 2374 orang \\
Kristen & 411 orang & 519 orang \\
Katholik & 403 orang & 386 orang \\
Hindu & 862 orang & 811 orang \\
Budha & 0 orang & 1 orang \\
\multicolumn{1}{c}{ Jumlah } & 4.214 orang & 4.091 orang \\
\hline
\end{tabular}

Sumber : Arsip Desa Bulurejo (2015-2019)

Bangsa Indonesia adalah bangsa memiliki keragaman yang begitu banyak, tidak hanya masalah adat istiadat, budaya, seni, bahasa dan ras, tetapi juga termasuk masalah agama. Walaupun mayoritas penduduk Indonesia memeluk agama Islam, ada beberapa agama dan keyakinan lain yang juga dianut penduduk ini. Kristen, Katolik, Hindu, Budha dan Khonghucu adalah contoh agama yang juga tidak sedikit dipeluk oleh warga Indonesia. Setiap agama tentu punya aturan masingmasing dalam beribadah.Namun perbedaan ini bukanlah alasan untuk berpecah belah. Sebagai satu saudara dalam tanah air yang sama, setiap warga Indonesia berkewajiaban menjaga kerukunan umat beragama di Indonesia agar negara ini tetap menjadi satu kesatuan yang utuh dan mencapau tujuannya sebagai negara yang makmur dan berkeadilan sosial (Hasan, 2013)

Dalam kehidupan sehari-hari masyarakat Desa Bulurejo menjunjung tinggi toleransi. Mereka hidup berdampingan dalam melakukan kegiatan dan rutinitas sehari-hari dan Ketika ada isu-isu tentang perpecahan atau konfik yang terjadi tentang keagamaan selalu berkumpul dan bermusyawarah bersatu untuk mengatasi permaslahan yang terjadi agar tidak menyebar dan merusak suasana keharmonisan dan kerukunan di Desa Bulurejo.

Peraturan bersama menteri agama dan menteri dalam negeri no. 9 tahun 2006/no. 8 tahun 2006, kerukunan umat beragama adalah keadaan hubungan semua umat beragama yang dilandasi toleransi, saling pengertian, saling mengormati, menghargai kesetaraan dalam pengalaman ajaran agama dan kerjasama dalam kehidupan bermasyarakat, berbangsa dan bernegara di dalam Negara kesatuan republik Indonesia berdasarkan pancasila dan Undang-undang dasar 1945.(Kementerian Hukum dan HAM: 2011 hlm. 16-17).

Toleransi masyarakat di Desa Bulurejo bisa dikatakan sangat tinggi, hal ini dibuktikan dengan saling menghargai saat pemeluk agama lain melakukan ibadah, 
serta sangat rukun dalam kegiatan atau acara yang diadakan oleh Desa. Di desa bulurejo terdapat satu dusun yaitu dusun tambakrejo di dusun tersebut terdapat tempat ibadah yang saling berdampingan yaitu Gereja dan Pura. Kedua tempat ibadah tersebut bisa melaksanakan ibadahnya masing-masing dengan hikmat tanpa ada pergesekan sedikitpun dan saling bisa menghargai satu dengan yang lain tanpa membedabedakan.

Rasa solidaritas yang tinggi ternyata sudah terbentuk dari nenek moyang dahulu, ketika ada acara keagamaan yang terjadi di dusun tersebut semua guyup rukun untuk melakukan secara bersama, bukan hanya acara besar keagamaan saja yang dilakukan secara bersama-sama, akan tetapi juga seluruh acara keagamaan yang lainya.

Desa Bulurejo merupakan desa yang unik karena disini memiliki banyak perbedaan namun mereka bisa hidup rukun dan berdampingan. Disini ada empat ajaran agama yang berbeda yang dianut oleh warga masyarakat yaitu Islam, Hindu, Kristen, katholik dan budha, mereka membaur menjadi satu dan bahkan jarak tempat ibadah yang ada bisa dikatakan berdekatan dan masyarakat menjalankan kegiatan keagamaanya dengan baik dan saling menghormati. Selain itu juga banyak kegiatan yang dilakukan oleh desa dan mereka dengan antusias melaksanakan kegiatan desa secara bersama-sama. Kegiatan yang dilakukan bersifat umum dan beragam antara satu dusun dengan dusun yang lainya, diantaranya terdapat kegiatan rutin yang dilakukan oleh dusun yang mengadakan pertemuan rutin dengan RT/RW yang melibatkan beberapa tokoh agama. Ada juga suatu kegiatan yang melibatkan agama lain seperti acara pengajian akbar, didalam acara tersebut umat islam mengundang beberapa tokoh agama Kristen dan hindu, dan juga terdapat partisipasi pemuda non muslim yang membantu mengamankan area yang digunakan untuk parkir kendaraan peserta pengajian.

Kerukunan antar umat bergama yang ada di Desa Bulurejo terbentuk karena rasa kebersamaan, guyup rukun dalam melakukan kegiatan, rasa peka atau sadar terhadap lingkungan dan rasa solidaritas bahwa perbedaan hanya dari segi ajaran kepercayaan dan prosesenya yang berbeda, namun juga mempunyai tujuan yang sama pada akhirnya. Jadi dalam masyarkat Desa Bulurejo kebersamaan menjadi nomor satu, itu terwujud ketika salah satu agama melakukan aktifitas, dengan rasa solidaritas yang tinggi umat agama lain membantu. Begitu juga ketika ada salah satu warga dusun mendirikan rumah warga yang lain pula yang membantu bergotong royong.

Bukan kegiatan keagamaan saja yang rutin dilakukan secara bersama dengan tokoh-tokoh agama, namun juga ada beberapa kegiatan yang dilakukan yang juga melibatkan tokoh-tokoh agama yaitu kegiatan bersih desa dan HUT-RI. Kegiatan bersih desa dilakukan satu tahun satu kali dengan acara doa bersama untuk kemajuan Desa Bulurejo, untuk terciptanya damai dan sejahtera di Desa Bulurejo, kegiatan ini dilakukan di pertigaan depan kantor Desa Bulurejo. Karena kondisi yang multi agama jadi untuk doa dan acara dipisahkan atau dikelompokan agar ketika melakukan doa tidak saling menggangu satu dengan yang lainya.

Selain itu atusias warga masyarakat dalam kegiatan HUT-RI sangat tinggi. Semua warga baik yang Islam, Kristen maupun Hindu guyup rukun bersamasama menampilkan atraksi-atraksi, seperti ogo-ogo umat hindu Dusun Tambakrejo, kebudayaan dan tarian dari GKJW (Gereja Kristen Jawi Wetan) Bulurejo, dan rebana remaja masjid Dusun Bulurejo dan Dusun Ngadimulyo

\section{Bentuk-Bentuk Kegiatan di Desa Bulurejo untuk mewujudkan kerukunan antar umat beragama}

Kegiatan-kegiatan yang dilakukan oleh desa dalam rangka mempererat kerukunan antar umat beragama di Desa Bulurejo, Kecamatan Purwoharjo dilakukan secara rutin. Adapun bentuk-bentuk kegiatan yang ada sesuai dengan hasil penelitian adalah:

\section{Pertemuan Lintas Agama}

Pertemuan lintas agama di lakukan di Desa Bulurejo setiap tiga bulan sekali, pertemuan ini melibatkan semua tokoh masyarakat seperti petua-petua desa, semua tokoh agama seperti Ustad-ustad, Pendetapendeta, Romo Mangku yang ada di Desa Bulurejo, adapun yang sering dibicaran dalam pertemuanpertemuan lintas agama yaitu seperti bagaimana kerukunan yang terjadi di dusun apakah dalam situasi yang baik-baik saja atau dalam situasi yang kurang baik. Lalu pertemuan yang diadakan oleh desa ini juga dilakukan saat akan ada acara keagamaan seperti pengajian akbar, dan acara-acara keagaman lainya.

\section{Kegiatan Bersih Desa}

Kegiatan bersih desa adalah acara rutin tahunan di Desa Bulurejo, acara ini merupakan acara doa bersama dengan masyarakat agar Desa Bulurejo tetap aman dan damai. Dalam acara bersih desa ini, desa mengundang semua masyarakat Desa Bulurejo yang bertempat di pertigaan depan Kantor Desa Bulurejo. Dalam acara ini semua masyarakat dikumpulkan jadi satu, artinya umat Islam dijadikan satu di satu blok atau wilayah, lalu umat Kristen dijadikan satu di satu blok atau wilayah, dan umat Hindu juga dijadikan satu blok atau wilayah. Akan tetapi dalam acara inti yaitu doa untuk desa, maka semua berdoa dengan iman dan kepercayaan masing-masing. 


\section{Kegiatan Keagamaan}

Tabel 3. Kegiatan Keagamaan

\begin{tabular}{ll}
\hline Keterangan & Kegiatan Keagamaan \\
\hline Agama Islam & $\begin{array}{l}\text { Idul Fitri, Idul Adha, Tahun Baru Hijriah, } \\
\text { Isra Mi’raj, Istigosah, Puasa Ramadhan, } \\
\\
\text { Maulid Nabi }\end{array}$ \\
Agama & Natal, Paskah, Pantekosta, Hari Jum'at \\
Kristen & Agung, Kenaikan Isa Almasih, Wafat Isa \\
& Almasih, Angkat Sidi \\
Agama & Natal, Paskah, Santopetrus dan Paulus, \\
Katolik & Kamis Putih, Jum'at Agung, Epifani \\
Agama Hindu & Nyepi, Saraswati, Galungan, Kuningan, \\
& Odalan
\end{tabular}

Sumber : Arsip Desa Bulurejo (2015-2019)

Semua agama memiliki hari raya besar masing masing. di Desa Bulurejo ketika salah satu agama merayakan hari rayanya, umat yang yang lainya juga guyup rukun untuk membantunya dan juga budaya berkunjung antar rumah ke rumah dalam satu dusun atau berkunjung antar rumah ke rumah dalam satu desa dan mengucapkan selamat merayakan hari raya kepada umat yang merayakan masih terjaga dengan baik.

Keurukan antar umat bergama yang ada di Desa Bulurejo terbentuk karena rasa kebersamaan, guyup rukun dalam melakukan kegiatan, rasa peka atau sadar terhadap lingkungan dan rasa solidaritas bahwa perbedaan hanya dari segi ajaran kepercayaan dan prosesenya yang berbeda, namun mempunyai tujuan yang sama pada akhirnya. Jadi dalam masyarkat Desa Bulurejo kebersamaan menjadi nomor satu, itu terwujud ketika salah satu agama melakukan aktifitas, dengan rasa solidaritas yang tinggi umat agama lain ikut membantu. Hal ini terwujud dalam kegiatan keagamaan yang dilakukan seringkali umat yang melakukan kegiatan juga melibatkan umat lainya, seperti misal saat idul fitri, idul adha dan istigosah melibatkan umat agama lainya dalam acara tersebut yaitu membatu pengamanan saat pelaksanaan. Begitu juga Ketika ada acara umat agama Hindu, Kristen maupun Katolik semua bahu membahu membantu kelancaran acara keagaman tersebut

\section{Kegiatan HUT RI}

Sudah menjadi agenda rutin yang dilaksanakan di Desa Bulurejo yaitu kegiatan memperingati HUT RI. Melalui kegiatan ini masyarakat baik itu Islam, Kristen, Katolik, dan Hindu ikut perpartisipasi langsung dan bahu membahu dalam mempersipakannya baik secara materiil maupun non materiil. Masyarakat desa Bulurejo secara sukarela dan gotong royong kerjabakti membersihkan kampung, menghiasi jalan dengan bendera merah putih, mengadakan kegiatan perlombaan-perlombaan, pawai budaya, dan juga kegiatan syukuran dengan memotong tumpeng merahputih sebagai symbol rasa syukur atas kemerdekaan yang diraih selama ini.

\section{SIMPULAN}

Desa Bulurejo merupakan desa yang multi agama yang memiliki keberagaman agama dan budaya. Desa Bulurejo memiliki kerukunan umat beragama yang bisa dikatakan sangat baik. Hal ini di tunjukan dengan kebersamaan dalam kehidupan sehari-hari serta melakukan berbagai macam bentuk kegiatan yang dilakukan secara bersama-sama diantaranya yaitu 1). Pertemuan lintas agama yang dilakukan setiap tiga bulan sekali; 2) Kegiatan bersih desa diikuti oleh semua warga masyarakat: 3). Kegiatan-kegiatan keagamaan yang dalam pelaksanaanya melibatkan umat lainya seperti kegiatan keagamaan umat Islam, umat hindu, umat kristen, umat Katolik, dan umat budha; 4). Kegiatan memperingati HUT RI.

\section{DAFTAR PUSTAKA}

Ardiansyah. (2017). Kerukunan Umat Beragama Antara Masyarakat Islam Dan Kristen di Kelurahan Paccinongang Kecamatan Somba Opu Kabupaten Gowa. Repository UIN Alauddin Makasar. Makasar. Hlm 2-30

Achmad Yusnedi. (2019). Sosiologi Politik. Grup Budi Utama. Yogyakarta.

Bakar Abu, Hurmain, (2016). Kerukunan antarumat beragama; Telaah Atas Piagam Madinah Dan Relevansinya Bagi Indonesia. E-Journal Toleransi: Media Komunikasi umat Beragama UIN Suska Riau. Vol. 8(2). Hlm 204-2016

Burhanuddin Muhamad. (2016). Toleransi Antar Umat Beragama Islam Dan Tri Dharma. Fakultas Ushuluddin dan Humaniora Universitas Islam Negeri Walisongo. Semarang. Eprints UIN Walisonggo. Semarang. Hlm 15-18

Hasan Kholiq M.A (2013). Merajut Kerukunan dalam Keberagamaan Agama di Indonesia. PROFETIKA, Jurnal Studi Islam, Vol. 14 (1). Hlm 66-77

Nurdin H Anasri. (2018). Membingkai dan Merajut Kerukunan Dalam Keragaman Agama Di Indonesia. Dikutip dari (http//riau.kemenag.go.id/artikel/42846/membingk ai-dan-merajut-kerukunan-dalam keagamaanagama-di-indonesia) diakses 20 September 2019.

Setyawan KG. (2018). Politik Dalam Masyarakat Multi Agama.. The journal of society and media Universitas Negeri Surabaya, Program Studi Sosiologi, vol. 3(1). Hlm 1-16

Sugiyono. (2017). Metodologi Penelitian Pendidikan. Alfabeta. Bandung.

Toha MA. (2005). Tren Pluralisme Agama: tinjauan kritis. Kelompok gema insansi. Jakarta.

(2017).Undang-Undang Dasar Tahun 1945. Sendang Ilmu. Solo

Waluya Bagja. (2007). Menyelami Fenomena sosial di Masyarakat. Setia Purna Invite. Bandung. 